\title{
Benefits of Progressively Increasing Container Size during Nursery Production Depend on Fertilizer Regime and Species
}

\author{
R.C. Beeson, Jr. ${ }^{1}$ \\ Central Florida Research and Education Center-Sanford, Institute of Food and Agricultural Sciences, \\ University of Florida, 2700 East Celery Avenue, Sanford, FL 32771
}

Additional index words. photinia, Photinia $\times$ fraseri, Pinus elliottii, shifting, slash pine, stepping up, transplanting, upcanning

\begin{abstract}
Rooted photinia (Photinia $\times$ fraseri) cuttings and hare-root slash pine (Pinus elliottii Engelm.) seedlings were transplanted initially into 0.9-, 2.9-, and 10.2-liter containers. A subset of these plants was transplanted from 0.9- and 2.9liter containers into the next larger container size in the series (upcanning) until representative plants of each initial container size were growing in 10.2-liter containers. The photinia experiment was conducted with two fertilizer regimes [soluble vs. controlled-release (CR) fertilizer] superimposed. When CR fertilizer was used, upcanning from 2.9- to 10.2liter containers produced the largest photinia. However, for pine, there was no advantage due to upcanning. When soluble fertilizer was used, photinia initially transplanted into 0.9-liter containers and upcanned to 2.9- and then to 10.2-liter containers had superior growth compared to those of other fertilizer $\times$ container combinations. Upcanning generally maintained or increased plant growth rate, while growth rates of plants kept in the same container generally declined the second season. Improved efficiency of the root system in nutrient absorption of upcanned plants is proposed as the mechanism for this response.
\end{abstract}

Two schools of thought exist in commercial nursery container production: liners should be transplanted directly into market-size containers or transplanted into small containers and later transferred into market-size containers (upcanning). While upcanning is more labor-intensive, it requires less space, provides more rapid shading of the container, which results in a cooler growth medium, and there is less capital loss with early plant failure (Beeson, 1991).

Nursery operators using upcanning assert that canopy growth is accelerated compared to direct transplanting into market-sized containers, thus reducing production time and overhead cost. Indirect evidence supports this contention. 'Elberta' Peach (Prunus persica L. Batsch) seedlings grown in liquid culture in $15-\mathrm{ml}$ vials then transferred to 500-ml flask had larger shoot : root ratios and more roots than those grown directly in a 500-ml flask (Richards and Rowe, 1977). Alder (Alnus glutinosa Gaertna.) seedlings grown in liquid culture in 16-ml vials grew more rapidly than similar seedlings in 500-ml containers for the first 65 days (Tschaplinski and Blake, 1985).

Generally, increased container size results in increased canopy growth, as shown for 'Bradford' pear (Pyrus calleryana Dcne.) (Gilliam et al., 1984), 'Elliott' pecan [Carya illinoinensis (Wangenh.) K Koch] (Keever et al., 1986), 'Microphylla' Japanese euonymus (Euonymus juponica Thunb.) (Keever and Cobb, 1987), and several other ornamental species (Appleton and Whitcomb, 1983; Biran and Eliassaf, 1980). Bilderback (1985) also found that larger Leyland cypress ( $X$ cupressocyparis leylandii) were produced in 11.4-liter than 3.8- or 7.6-liter containers after two growing seasons, although after the first season, container size had no effect on growth indexes. In these studies, liners were grown in containers in which they were initially transplanted. In upcanning, plants are grown in small premarket-size containers

Received for publication 30 Oct. 1992. Accepted for publication 21 Apr. 1993 Univ. of Florida Agricultural Experiment Station Journal series no. R-02744. Use of trade names does not imply endorsement of products nor criticism of similar products not mentioned. The cost of publishing this paper was defrayed in part by the payment of page charges. Under postal regulations, this paper therefore must be hereby marked advertisement solely to indicate this fact.

${ }^{1}$ Assistant professor. until the roots fill the containers, then shifted to larger containers to avoid the effects of restricted root systems (Harris et al., 1971; Richards and Rowe, 1977; Tschaplinski and Blake, 1985), as may have occurred in previous studies.

The objectives of this study were to 1) compare upcanning with production in final market containers and 2) compare the effects of soluble and top-dressed controlled-release (CR) fertilizer on plant growth in various container sizes.

\section{Material and Methods}

Single 'Red Tip' Photinia $\times$ fraseri rooted cuttings and bare-root seedlings of Pinus elliottii Engelm. (slash pine) were transplanted initially in 0.9- (1-), 2.9- (3-), and 10.2-liter (10-liter) black polyethylene containers using a 3 pine bark fine : 1 Florida peat : 1 coarse sand medium. The medium was amended with $0.89 \mathrm{~kg}$ of micronutrients per cubic meter (Micromax; Grace-Sierra Chemical Co., Milpitas, Calif.). Within 1 week after potting, each plant received $\approx 75 \mathrm{mg} \mathrm{N}$ from soluble fertilizer (Peter's 20N-8.7P16.6K; Grace-Sierra Chemical Co.). All plants were grown in full sun and were irrigated daily at $0530 \mathrm{HR}$ with impact sprinklers for $30 \mathrm{~min}$ at $20 \mathrm{~mm} \cdot \mathrm{h}^{-1}$. Irrigation was decreased to every other day from December through February.

Two-thirds of the liners initially transplanted into 1-liter containers (1-1) was upcanned to 3-liter containers (1-3) when the root systems filled the containers (Fig. 1). Half of the plants in 13 containers was upcanned to 10-liter containers (1-3-10) when the root systems again filled the containers. Half of the liners initially transplanted into 3-liter containers (3-3) was upcanned into lo-liter containers (3-10) when root development was sufficient. Liners initially transplanted into lo-liter containers (10-10) were grown in these containers throughout the 2-year production period. For Expts. 1 and 3, 60, 40, and 20 liners were used initially for transplanting into 1-, 3-, and 10-liter containers, respectively. The number for each container size was doubled for Expt. 2. Treatments were placed randomly in the growing area, with the placement of the treatments that were upcanned rerandomized with each upcanning step. 


\section{CONTAINERIZED}

HARVESTED

10 LITER

10 LITER

(10-10)

3 LITER

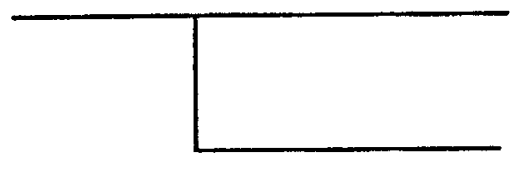

3 LITER

10 LITER $(3-10)$

\section{LITER}

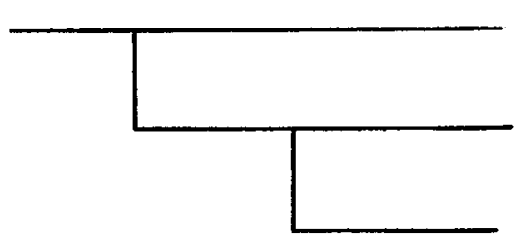

1 LITER (1-1)

3 LITER (1-3)

10 LITER (1-3-10)

Fig. 1. Flow diagram indicating the direction of upcanning steps, where $1-1=$ plants in 1-liter containers, $1-3=1-1$ plants upcanned to 3-liter containers, $1-3-10=$ 1-3 plants upcanned to 10 -liter containers, $3-3=$ plants in 3-liter containers, $3-$ $10=3-3$ plants upcanned to 10 -liter containers, and $10-10=$ plants in 10 -liter containers.

Plants were top-dressed by hand with one of two CR fertilizers. One was a 4-month fertilizer (Osmocote 14N-6.2P-11.6K; GraceSierra Chemical Co.) applied every 2 months at rates of $0.42,0.84$, and $5.0 \mathrm{~g} \mathrm{~N}$ for 1-, 3-, and 10-liter containers, respectively. The other fertilizer was labeled as 8- to 9-month release (Osmocote 18N-2.6P-9.9K; Grace-Sierra Chemical Co.) and was applied every 4 months at rates of $1.1,2.2$, and $9 \mathrm{~g} \mathrm{~N}$ for the 1-, 3-, and 10liter containers, respectively. The hot, humid growing season in Florida reduces the release time of these fertilizers by about one-half (Richard Johnson, personal communication, Grace-Sierra Chemical Co.).

Photinia, CR fertilizer (Expt. 1). Rooted photinia cuttings were transplanted singly into each size of container on 14 Mar. 1990. One liter plants were upcanned to 1-3 on 6 Sept. 1990, with half further upcanned to 1-3-10 on 11 Mar. 1991. Half of the 3-3 plants was upcanned to 3-10 on 3 Jan. 1991. Plants were fertilized as described above with $14 \mathrm{~N}-6.2 \mathrm{P}-11.6 \mathrm{~K}$ on 16 Mar., 3 May, 10 July, and 7 Sept. 1990 and with 18N-2.6P-9.9K on 20 Mar. and 24 June 1991.

Photinia, CR, and soluble fertilizer (Expt. 2). Rooted photinia cuttings were transplanted singly into each size of container on 6 June 1990. Two-thirds of the 1-1 plants was upcanned to 1-3 on 29 Oct. 1990, with half further upcanned to 1-3-10 on 8 Mar. 1991. Half of the 3-3 plants was upcanned to 3-10 on 3 Jan. 1991.

Two fertilization treatments were superimposed on the upcanning treatments in this experiment. Plants were either fertilized as described above with a CR fertilizer or a soluble compound (Peter's 20N-8.7P-16.6K) applied weekly by hand, using a siphon applicator (Hyponex, Atlanta). Soluble fertilization rates of $0.8 \mathrm{~g}$ N/liter of water (after dilution) per week were applied such that total $\mathrm{N}$ per year was similar in solution and CR treatments. CR fertilizer (18N-2.6P-9.9K) was applied on 6 July 1990 and 20 Mar. and 24 June 1991. Weekly soluble fertilization occurred from 6 July until 29 Oct. 1990. Soluble fertilization was resumed on 20 Mar. 1991 and continued until 22 Oct. 1991.

Slash pine, CR fertilizer (Expt. 3). Slash pine seedlings, field-grown 1 year before lifting, were obtained bare-root in late Feb. 1990, stored at 2C, and transplanted singly into each size of container on 27 Feb. 1990. Forty trees in 1-liter containers were upcanned to 1-3 on 23 Aug. 1990, of which one-half was again upcanned to 1-3-10 on 8 Mar. 1991. Half of the 3-3 trees was upcanned to 3-10-liter containers on 9 Jan. 1991. Trees were fertilized as described for Expt. 1.

Growth measurements. Initial shoot heights and stem diameters were measured (at $25 \mathrm{~mm}$ above the medium) within 2 weeks of initial transplanting for all experiments, with measurements repeated on all plants every 2 to 3 months until the final ones were taken in November 1991. On 15 Nov. 1991, shoots of 10 plants from each experimental unit were severed at the medium surface and dried at $60 \mathrm{C}$ to constant dry weight.

Plant dry weight, final stem diameter, and height for Expts. 1 and 3 were analyzed as a randomized design of six treatments (combination of initial and final container size), with 10 (shoot dry weight only) or 20 replications per treatment. Expt. 2 was analyzed as a split-plot, with fertilizer type as the main plot and six container treatments as subplots in a randomized design. Growth rates for height and trunk diameter were separated into two growth periods consistent with the 1990 and 1991 growing seasons for easier analysis. The first season extended from Week 5 to 32 for Expt. 1, Week 2 to 27 for Expt. 2, and Week 13 to 37 for Expt. 3. The second season consisted of the intervals Weeks 42 to 87 for Expt. 1, Weeks 36 to 73 for Expt. 2, and Weeks 48 to 89 for Expt. 3. Growth rates were analyzed by regression for each experiment and growth season. Single-degree-of-freedom contrast was used to compare slopes among the container treatments as describe by Snedecor and Cochran (1980). All analyses used the SAS (SAS Institute, Cary, N.C.) statistical package.

\section{Results}

Final growth measurements. For the photinia, in both experiments, shoots of plants in 3-10 or 1-3-10 grew more than those in the other treatments. The treatment that produced maximum shoot growth depended on the fertilizer regime.

Photinia transplanted into 3-liter containers, top-dressed with $\mathrm{CR}$ fertilizer, and later upcanned into lo-liter containers (3-10) were significantly $(\alpha \leq 0.05)$ taller and had thicker stems than those grown with the other CR fertilizer treatments in Expts. 1 and 2 (Tables 1 and 2). Among plants supplied with CR fertilizer, 3-10 plants accumulated the most dry mass in either experiment and were larger than 1010 plants in both experiments (Tables 1 and 2).

Plants that received soluble fertilizer and initially were transplanted into 1-liter containers and then upcanned to the 10-liter containers (1-3-10) were as tall and accumulated dry mass similar to those fertilized with $\mathrm{CR}$ in 3-10 (Table 2). However, CR-fertilized 3-10 plants had thinner $(\alpha \leq 0.05)$ stems than those with soluble fertilizer in 1-3-10. CR-fertilized 1-3-10 plants were smaller by all growth indexes than plants in 1-3-10 fertilized by solution, whereas the opposite was true for the 10-10 plants. For the other container treatments, there were generally no differences between solution and CR fertilization within a treatment.

In contrast to photinia, slash pine seedlings transplanted directly into 10-liter containers (10-10) were similar to those upcanned from 3-liter containers (3-10; Table 3). Plants in both treatments produced more shoot growth than those upcanned from 1-liter containers (1-3-10).

Growth rate analysis, Photinia (Expt. 1). During the first season, photinia liners initially transplanted into 3-liter containers (3-3 and 3-10) increased in height and stem diameter most rapidly, 
while those transplanted into the 1-liter containers grew the slowest (Table 1). However, during the second growing season, plants from 3-10 and 1-3-10 had the highest growth rates for height and stem diameter (Table 1). During the second season, photinia plants upcanned to 10-liter containers grew significantly faster than the 10-10 plants.

Photinia, CR, and soluble fertilizer (Expt. 2). The fertilizer regime $\times$ container treatment interaction was significant; thus, the growth rates of all 12 treatment combinations were compared. During the first growing season, height growth rates were higher for those plants initially transplanted into 3- or 10-liter containers and supplied with CR fertilizer than plants in 1-liter containers or supplied with fertilizer in solution (Table 2). Growth rates of the CR-fertilized plants were higher $(\alpha \leq 0.05)$ than plants grown in the same sized containers and fertilized with solution (Table 2). Plants initially transplanted into 3- and 10-liter containers and supplied with fertilizer in solution generally had the slowest height increase. Height growth rates were similar for solution and CR-fertilized plants transplanted into 1-liter containers.

Stem diameter increases were also larger the first season for plants transplanted into 3-liter containers than for those in other container sizes (Table 2). Unlike for height growth rate, fertilizer type was less important than initial container size for stem diameter growth. Stem diameter increases were the same for solution and CR-fertilized plants within a container treatment, except for the 33 and 10-10 treatments. For both of these, plants fertilized with CR fertilizer had higher $(\alpha \leq 0.05)$ growth rates than their solution counterparts. Stem diameter growth rates were lowest for plants transplanted into 1-liter containers.

During the second growing season, height and stem diameter growth rates were higher for plants upcanned into 10-liter containers (1-3-10 and 3-10; Table 2). Of these, solution-fertilized 1-310 plants had the highest height growth rates followed by CRfertilized 3-10 (Table 2). Solution-fertilized 1-3-10 plants had higher height growth rates $(\alpha \leq 0.05)$ than similarly fertilized 10 10 plants and larger increases in stem diameter than CR-fertilized 3-10 plants. Plants transplanted and maintained in 1-liter containers generally had the slowest growth rates, independent of fertilizer regime. During the second season, height growth rates were the same between solution- and CR-fertilized plants within a container treatment with one exception; solution-fertilized 3-3 plants grew faster than CR-fertilized 3-3 plants. Stem diameter growth was also similar between solution- and CR-fertilized plants within a container treatment, except for 1-3-10 plants (Table 2).

Height growth rates of solution-fertilized 1-3-10 plants increased between the first and second season but declined for all 11 and 1-3 plants and CR-fertilized 3-3 and 10-10 plants (Table 2). Stem diameter growth rates of solution-fertilized 1-3-10 plants also increased but decreased for all 1-3 and 3-3 plants and CR fertilized 1-1 and 10-10 plants during the second season (Table 2).

Slash pine (Expt. 3). During the first growing season, height and stem diameters of 10-10 plants increased faster than those for other treatments (Table 3). Trees transplanted into 3-liter containers increased in height more than those transplanted into 1-liter containers. Trees in all containers increased in stem diameter at similar rates, except for 10-10 plants.

During the second growing season, trees upcanned to 10-liter containers (3-10 and 1-3-10) increased in height at a higher rate than 10-10 trees (Table 3). Stem diameter growth rates for these upcanned trees were also higher, although not significantly different than those for 10-10 trees. Both 3-10 and 1-3-10 trees had higher height and stem diameter growth rates than trees remaining in 3- or 1-liter containers.
Mean height growth rates increased in the second season over the first for 3-10 and all trees initially transplanted into 1-liter containers but decreased compared to the first season for those of the 3-3 and 10-10 trees. Stem diameter growth was less for all treatments the second season.

\section{Discussion}

Shoot growth benefits derived from upcanning during production seem to depend on species and further study may distinguish this response based on root-system characteristics. While there were no growth benefits of upcanning slash pine from 3-liter containers to the final 10-liter market container, photinia shoot growth was increased by upcanning. Pine has a coarser root system than photinia and seems to benefit from a larger initial container volume. The effect of container size on pine growth was similar to that previously reported using other tree species (Appleton and Whitcomb, 1983; Bilderback, 1985; Gilliam et al., 1984; Hanson et al., 1987; Keever et al., 1986). The effect of container size on photinia growth differed from that reported for Japanese euonymus and azalea (Rhododendron spp.) (Keever and Cobb, 1987). However, euonymus and azaleas grown in smaller containers were not upcanned to the largest size used in these studies.

Root restriction results in decreased canopy growth (Hanson et al., 1987; Richards and Rowe, 1977; Ruff et al., 1987; Tschaplinski and Blake, 1985). Root restriction was also observed in this study on plants grown in containers $<10$ liters, the maximum size used. Yet, before root restriction, seedlings grown in small containers had faster shoot growth than their counterparts grown in larger containers (Richards and Rowe, 1977; Tschaplinski and Blake, 1985). Upcanning seems to take advantage of more rapid growth in smaller containers while avoiding the problems of root restriction. During the first season of the present study, CR-fertilized photinia (Expts. 1 and 2) initially transplanted into 3-liter containers had higher height and stem diameter growth rates than those transplanted directly into 10-liter containers. With upcanning into 10-liter containers early in the second season, growth rates were maintained or increased, while those of plants grown continuously in 10-liter containers declined.

Fertilizer regime influenced the benefits obtained from upcanning. When fertilized with a soluble compound, final market growth was superior for plants in the 1-3-10 system. This difference was more the result of greater increases in growth during the second growing season compared to other treatments than of growth rates the first season. When CR-fertilized throughout production, transplanting directly into the 3-liter container and upcanning to the lo-liter container produced superior growth.

Upcanning may improve growth by increasing efficiency of absorption of nutrients or water by the root system. This increased efficiency likely is the result of increased fine diameter root mass with each upcanning. Most nutrients and water are absorbed by roots $<2 \mathrm{~mm}$ in diameter (Linder et al., 1987). For container-grown plants, the fine-root mass is concentrated at the periphery of the rootball, while roots in the center serve mainly for transport (Biran and Eliassaf, 1980). By upcanning, fine-root mass may be better distributed and perhaps more numerous than in plants grown in the final market-size container. If the fine-root mass on the container periphery remains viable, upcanning from a 1- to a 3-liter container or from a 3- to a 10-liter container used here would have increased the surface area of the rootball $43 \%$ ([smaller container surface area + larger container surface area]/larger container surface area) compared to that of the larger container only. Upcanning from a 1to a 3 - and then to a 10-liter container would increase the surface 
Table 1. Shoot growth measurements at harvest and growth rates during the 2-year production cycle for photinia (Expt. 1).

\begin{tabular}{|c|c|c|c|c|c|c|c|}
\hline \multirow[b]{3}{*}{ Treatment } & \multirow{3}{*}{$\begin{array}{c}\text { Canopy } \\
\text { dry wt } \\
\text { (g) }\end{array}$} & \multirow{3}{*}{$\begin{array}{c}\text { Shoot } \\
\text { ht } \\
\text { (cm) }\end{array}$} & \multirow{3}{*}{$\begin{array}{l}\text { Stem } \\
\text { diam } \\
(\mathrm{cm})\end{array}$} & \multicolumn{4}{|c|}{ Growth rate $(\mathrm{mm} /$ week$)$} \\
\hline & & & & \multicolumn{2}{|c|}{ Weeks 5 to 32} & \multicolumn{2}{|c|}{ Weeks 42 to 87} \\
\hline & & & & $\mathrm{Ht}$ & Diam & $\mathrm{Ht}$ & Diam \\
\hline$\overline{1-1^{y}}$ & $44.9 \mathrm{e}^{\mathrm{x}}$ & $92.2 \mathrm{c}$ & $1.22 \mathrm{e}$ & $18 \mathrm{~b}$ & $0.07 \mathrm{~b}$ & $8 \mathrm{e}$ & $0.09 \mathrm{~d}$ \\
\hline $1-3$ & $81.3 \mathrm{~d}$ & $122.0 \mathrm{~b}$ & $1.54 \mathrm{~d}$ & $14 \mathrm{c}$ & $0.02 \mathrm{c}$ & $14 \mathrm{c}$ & $0.14 \mathrm{c}$ \\
\hline $1-3-10$ & $176.1 \mathrm{~b}$ & $132.8 \mathrm{~b}$ & $2.08 \mathrm{~b}$ & $14 \mathrm{c}$ & $0.06 \mathrm{~b}$ & $17 \mathrm{~b}$ & $0.27 \mathrm{~b}$ \\
\hline $3-3$ & $113.3 \mathrm{c}$ & $130.3 \mathrm{~b}$ & $1.78 \mathrm{c}$ & $28 \mathrm{a}$ & $0.18 \mathrm{a}$ & $11 \mathrm{~d}$ & $0.13 \mathrm{c}$ \\
\hline $3-10$ & $288.1 \mathrm{a}$ & $164.3 \mathrm{a}$ & $2.49 \mathrm{a}$ & $26 a$ & $0.17 \mathrm{a}$ & $21 \mathrm{a}$ & $0.32 \mathrm{a}$ \\
\hline $10-10$ & $79.7 \mathrm{~d}$ & $91.7 \mathrm{c}$ & $1.90 \mathrm{bc}$ & $18 \mathrm{~b}$ & $0.11 \mathrm{~b}$ & $8 \mathrm{e}$ & $0.17 \mathrm{c}$ \\
\hline
\end{tabular}

${ }_{\mathrm{z}}$ Means of 20 one-plant replications/treatment. Mean separation within columns at $\alpha \leq 0.05$ calculated by single-degree-of-freedom contrast. y $1-1$ Liners transplanted and grown in 1-liter containers; $1-3=1$-liter plants upcanned to 3-liter containers; $1-3-10=1-3$ plants upcanned to 10 -liter containers; $3-3=$ liners transplanted and grown in 3-liter containers; $3-10=3-3$ plants upcanned to 10 -liter containers; $10-10=$ liners transplanted and grown in 10-liter containers.

${ }^{x}$ Means of $10(\mathrm{~g})$ and $20(\mathrm{~cm})$ one-plant replications/treatment. Mean separation in columns at $\alpha \leq 0.05$ calculated using Fisher's protected LSD.

Table 2. Canopy growth measurements at harvest and growth rates during the 2-year production cycle for photinia (Expt. 2). Plants were top-dressed with a controlled-release fertilizer (CR) or with fertilizer in solution (S) using a siphon device. The fertilizer regime $\times$ container treatment interactions were significant $(\alpha \leq 0.05)$. Mean separations are continuous within a column.

\begin{tabular}{|c|c|c|c|c|c|c|c|}
\hline \multirow[b]{3}{*}{ Treatment } & \multirow{3}{*}{$\begin{array}{l}\text { Canopy } \\
\text { dry wt } \\
\text { (g) }\end{array}$} & \multirow{3}{*}{$\begin{array}{c}\text { Shoot } \\
\text { ht } \\
(\mathrm{cm})\end{array}$} & \multirow{3}{*}{$\begin{array}{l}\text { Stem } \\
\text { diam } \\
(\mathrm{cm})\end{array}$} & \multicolumn{4}{|c|}{ Growth rate $(\mathrm{mm} /$ week $)$} \\
\hline & & & & \multicolumn{2}{|c|}{ Weeks 2 to 27} & \multicolumn{2}{|c|}{ Weeks 36 to 73} \\
\hline & & & & $\mathrm{Ht}$ & Diam & $\mathrm{Ht}$ & Diam \\
\hline \multicolumn{8}{|l|}{$\overline{\mathrm{CR}}$} \\
\hline $1-1^{y}$ & $52.6 \mathrm{e}^{\mathrm{x}}$ & $100.9 \mathrm{f}$ & $1.20 \mathrm{f}$ & $21 \mathrm{bc}$ & $0.19 \mathrm{de}$ & $6 \mathrm{~d}$ & $0.06 \mathrm{f}$ \\
\hline $1-3$ & $103.9 \mathrm{c}-\mathrm{e}$ & $134.8 \mathrm{~cd}$ & $1.54 \mathrm{e}$ & $24 \mathrm{a}-\mathrm{c}$ & $0.21 \mathrm{~cd}$ & $14 \mathrm{c}$ & $0.16 \mathrm{c}-\mathrm{e}$ \\
\hline $1-3-10$ & $144.9 \mathrm{bc}$ & $155.7 \mathrm{~b}$ & $1.77 \mathrm{c}$ & $22 \mathrm{bc}$ & $0.21 \mathrm{~cd}$ & $21 a b$ & $0.21 \mathrm{bc}$ \\
\hline $3-3$ & $115.5 \mathrm{~cd}$ & $129.4 \mathrm{de}$ & $1.69 \mathrm{~cd}$ & $28 \mathrm{a}$ & $0.29 \mathrm{a}$ & $8 \mathrm{~d}$ & $0.14 \mathrm{de}$ \\
\hline $3-10$ & $196.5 \mathrm{ab}$ & $169.6 \mathrm{a}$ & $2.00 \mathrm{~b}$ & $24 a b$ & $0.23 \mathrm{bc}$ & $23 a b$ & $0.24 \mathrm{~b}$ \\
\hline $10-10$ & $127.7 \mathrm{~cd}$ & $143.8 \mathrm{c}$ & $1.78 \mathrm{c}$ & $23 a-c$ & $0.23 \mathrm{~b}-\mathrm{d}$ & $16 \mathrm{bc}$ & $0.17 \mathrm{~b}-\mathrm{e}$ \\
\hline \multicolumn{8}{|l|}{$\mathbf{S}$} \\
\hline $1-1$ & $48.0 \mathrm{e}$ & $94.1 \mathrm{f}$ & $1.28 \mathrm{f}$ & $21 \mathrm{~b}-\mathrm{d}$ & $0.15 \mathrm{f}$ & $7 \mathrm{~d}$ & $0.13 \mathrm{e}$ \\
\hline $1-3$ & $96.7 \mathrm{c}-\mathrm{e}$ & $137.7 \mathrm{~cd}$ & $1.53 \mathrm{e}$ & $23 \mathrm{bc}$ & $0.20 \mathrm{~cd}$ & $14 \mathrm{c}$ & $0.15 c-e$ \\
\hline $1-3-10$ & $235.5 \mathrm{a}$ & $167.9 \mathrm{a}$ & $2.19 \mathrm{a}$ & $22 \mathrm{bc}$ & $0.21 \mathrm{~cd}$ & $26 \mathrm{a}$ & $0.36 \mathrm{a}$ \\
\hline $3-3$ & $100.5 \mathrm{c}-\mathrm{e}$ & $143.0 \mathrm{c}$ & $1.58 \mathrm{de}$ & $21 b-d$ & $0.22 b-d$ & $20 \mathrm{~b}$ & $0.18 \mathrm{~b}-\mathrm{d}$ \\
\hline $3-10$ & $184.5 \mathrm{ab}$ & $139.8 \mathrm{~cd}$ & $1.96 \mathrm{~b}$ & $19 \mathrm{~cd}$ & $0.25 \mathrm{ab}$ & $19 \mathrm{bc}$ & $0.25 \mathrm{~b}$ \\
\hline $10-10$ & $82.6 \mathrm{de}$ & $119.1 \mathrm{e}$ & $1.51 \mathrm{e}$ & $16 \mathrm{~d}$ & 0.16 ef & $18 \mathrm{bc}$ & $0.18 \mathrm{~b}-\mathrm{e}$ \\
\hline
\end{tabular}

${ }^{\mathrm{z}}$ Means of 20 one-plant replications/treatment. Mean separation within columns at $\alpha \leq 0.05$ calculated by single-degree-of-freedom contrast.

$y_{1-1}=$ Liners transplanted and grown in 1-liter containers; $1-3=1$-liter plants upcanned to 3 -liter containers; $1-3-10=1-3$ plants upcanned to 10 -liter containers; $3-3=$ liners transplanted and grown in 3-liter containers; 3-10=3-3 plants upcanned to 10-liter containers; $10-10=$ liners transplanted and grown in 10-liter containers.

${ }^{x}$ Means of $10(\mathrm{~g})$ and $20(\mathrm{~cm})$ one-plant replications/treatment. Mean separation in columns at $\alpha \leq 0.05$ calculated using Fisher's protected LSD.

Table 3. Shoot growth measurements at harvest and growth rates during the 2-year production cycle for slash pine (Expt. 3).

\begin{tabular}{|c|c|c|c|c|c|c|c|}
\hline \multirow[b]{3}{*}{ Treatment } & \multirow{3}{*}{$\begin{array}{l}\text { Canopy } \\
\text { dry wt } \\
\text { (g) }\end{array}$} & \multirow{3}{*}{$\begin{array}{c}\text { Shoot } \\
\text { ht } \\
(\mathrm{cm})\end{array}$} & \multirow{3}{*}{$\begin{array}{l}\text { Stem } \\
\text { diam } \\
(\mathrm{cm})\end{array}$} & \multicolumn{4}{|c|}{ Growth rate ${ }^{z}(\mathrm{~mm} /$ week $)$} \\
\hline & & & & \multicolumn{2}{|c|}{ Weeks 13 to 37} & \multicolumn{2}{|c|}{ Weeks 48 to 89} \\
\hline & & & & $\mathrm{Ht}$ & Diam & $\mathrm{Ht}$ & Diam \\
\hline$\overline{1-1^{y}}$ & $38.4 d^{x}$ & $71.2 \mathrm{e}$ & $1.36 \mathrm{~d}$ & $4 \mathrm{c}$ & $0 . \overline{18 c}$ & $7 \mathrm{c}$ & $0.08 \mathrm{~b}$ \\
\hline $1-3$ & $92.7 \mathrm{c}$ & $85.2 \mathrm{~d}$ & $1.71 \mathrm{c}$ & $5 \mathrm{c}$ & $0.24 \mathrm{~b}$ & $10 \mathrm{c}$ & $0.10 \mathrm{~b}$ \\
\hline $1-3-10$ & $274.1 \mathrm{~b}$ & $123.3 \mathrm{~b}$ & $2.36 \mathrm{~b}$ & $5 \mathrm{c}$ & $0.27 \mathrm{~b}$ & $19 \mathrm{a}$ & $0.20 \mathrm{a}$ \\
\hline $3-3$ & $110.3 \mathrm{c}$ & $101.6 \mathrm{c}$ & $1.86 \mathrm{c}$ & $14 \mathrm{~b}$ & $0.24 \mathrm{~b}$ & $9 \mathrm{c}$ & $0.10 \mathrm{~b}$ \\
\hline $3-10$ & $311.9 \mathrm{ab}$ & $142.2 \mathrm{a}$ & $2.79 \mathrm{a}$ & $14 \mathrm{~b}$ & $0.27 \mathrm{~b}$ & $19 \mathrm{a}$ & $0.23 \mathrm{a}$ \\
\hline $10-10$ & $328.3 \mathrm{a}$ & $140.6 \mathrm{a}$ & $2.76 \mathrm{a}$ & $19 \mathrm{a}$ & $0.49 \mathrm{a}$ & $15 \mathrm{~b}$ & $0.13 \mathrm{ab}$ \\
\hline
\end{tabular}

${ }_{\mathrm{z}}$ Means of 20 one-plant replications/treatment. Mean separation within columns at $\alpha \leq 0.05$ calculated by single-degree-of-freedom contrast.

$\mathrm{y}_{1-1}=$ Liners transplanted and grown in 1-liter containers. $1-3=1$-liter plants upcanned to 3-liter containers; $1-3-10=1-3$ plants upcanned to 10-liter containers; $3-3=$ liners transplanted and grown in 3-liter containers; $3-10=3-3$ plants upcanned to 10 -liter containers; $10-10=$ liners transplanted and grown in 10-liter containers.

${ }^{\mathrm{x}}$ Means of $10(\mathrm{~g})$ and $20(\mathrm{~cm})$ one-plant replications/treatment. Mean separation in columns at $\alpha \leq 0.05$ calculated using Fisher's protected LSD. 
area $63 \%$ compared to that of a 10-liter container. This increased surface area may explain why the largest photinia at the end of the 2-year production cycle were not those that had the highest growth rates the first growth season, but those with growth rates that were maintained or increased the season after being upcanned. Plants with higher root densities would be able to absorb more nutrients moving through the container (Barley, 1970). Higher absorption of nutrients may explain why plants upcanned from 1- to 10-liter containers (1-3-10) and fertilized with a soluble compound were larger than those of the other treatments, even though the growth rates were intermediate the first growing season. Less uniform distribution of $\mathrm{CR}$ fertilizer over the surface of the containers compared to soluble fertilization may explain why CR-fertilized 1-3-10 plants did not preform as well as their solution-fertilized counterparts.

All plants were irrigated equally during the 2 years of production. Plants remaining in the smaller containers were probably water stressed during the afternoons, especially during the second growing season. Limited available moisture in the container, in conjunction with root restrictions, reduced growth rates and resulted in smaller final growth from plants remaining in the 1- and 3-liter containers compared to those upcanned to 10-liter containers. However, available container moisture was the same for all plants in the 10-liter containers. Irrigation was uniform when irrigated during the early morning hours when there was no wind. Differences in growth rates among treatments of photinia in the 10liter containers during the second season and final growth do not appear due to differences in available container moisture, although the amount of water absorbed may have been unequal due to higher root densities.

\section{Literature Cited}

Appleton, B. and C.E. Whitcomb. 1983. Effects of container size and transplant date on the growth of tree seedlings. J. Environ, Hort. 1:89-93.

Barley, K.P. 1970. The configuration of the root system in relation to nutrient uptake. In: N.C. Brady (ed.). Advances in agronomy. Academic Press, New York. p. 22:159-201.

Beeson, R.C., Jr. 1991. Scheduling woody plants for production and harvest. HortTechnology 1:30-36.

Bilderback, T.E. 1985. Growth response of leyland cypress to media, N application and container size after 1 and 2 growing seasons. J. Environ. Hort. 3:132-135.

Biran, I. and I. Eliassaf. 1980. The effect of container size and aeration conditions on growth of roots and canopy of woody plants. Scientia Hort. 12:385-394.

Gilliam, C.H., G.S. Cobb, and C.E. Evans. 1984. Effects of nitrogen concentration and container size on growth of Pyrus calleryana 'Bradford'. J. Environ. Hort. 2:53-56.

Hanson, P.J., R.K. Dixon, and R.E. Dickson. 1987. Effect of container size and shape on the growth of northern red oak seedlings. HortScience 22:1293-1295.

Harris, R.W., W.B. Davis, N.W. Stice, and D. Long. 1971. Influence of transplanting time in nursery production. J. Amer. Soc. Hort. Sci. 96: 109-110.

Keever, G.J. and G.S. Cobb. 1987. Effects of container volume and fertility rate on growth of two woody ornamentals. HortScience 22:891893.

Keever, G.J., G.S. Cobb, and R. McDaniel. 1986. Effects of container size, root pruning, and fertilization on growth of seedling pecans. J. Environ. Hort. 4:11-13.

Linder, S., M.L. Benson, B.J. Myers, and R.J. Raison. 1987. Canopy dynamics and growth of Pinus radiata. I. Effects of irrigation and fertilization during a drought. Can. J. For. Res. 17:1157-1165.

Richards, D. and R.N. Rowe. 1977. Effects of root restriction, root pruning and 6-benzlyaminopurine on the growth of peach seedlings. Ann. Bot. 41:729-740.

Ruff, MS., D.T. Krizek, R.M. Mirecki, and D.W. Inouye. 1987. Restricted root zone volume: Influence on growth and development of tomato. J. Amer. Soc. Hort. Sci. 112:763-769.

Snedecor, G.W. and W.G. Cochran. 1980. Statistical methods. 7th ed. Iowa State Univ. Press, Ames. p. 507.

Tschaplinski, T.J. and T.J. Blake. 1985. Effects of root restriction on growth correlations, water relations and senescence of alder seedlings. Physiol. Plant. 64:167-176. 